\title{
Taxonomic diversity of mosses in the area of graduation towers in the town of Ciechocinek
}

\author{
Wanda Gugnacka-Fiedor \\ Department of Taxonomy and Plant Geography, Institute of Ecology and Environment Protection, \\ Faculty of Biology and Earth Sciences, Nicolaus Copernicus University, \\ Gagarina 9, 87-100 Torun, Poland \\ e-mail:wgfiedor@biol.uni.torun.pl
}

\begin{abstract}
Summary. The floral research on bryophytes was conducted in 2010 and 2011 in the area of three graduation towers in the Spa Park, as well as in the nature reserve of halophytes in Ciechocinek, in the Kujawy region. The research revealed the presence of numerous moss species -84 species, including five partially protected and three strictly protected ones. Nine species were recognized as the most frequent taxa within the research area, including 4 species of orthotropic mosses and 5 species of plagiotropic mosses.
\end{abstract}

Key words: flora, bryophytes, species richness, protected species, salt production, saline meadows, nature reserve of halophytes.

\section{Introduction}

The early days of floristic researches in the town of Ciechocinek date back to the 19th century, but already in 1820 the then squire, Mr. Zawadzki wrote to the publisher of „Izis Polska”: „everywhere herbs and even grasses, those which grow in the vicinity of this spring are salty, and right there a herb grows, which herewith I'm sending to you. It is salty and when ripe, no beast touches it”. Saline springs in the neighbourhood of Ciechocinek have existed since a very long time, and humans contributed to a considerable increase in the concentration of salts in the surface waters by building the graduation towers and by drilling deep boreholes through which brine come up to the surface.

The floristic research in Ciechocinek was concentrated mainly on vascular plants, especially halophytes belonging to those group. A preliminary assumption was made about the occurrence and the diversity of bryophytes in the saline environments. The main purpose of the research was to study the diversity of bryophytes in the areas situated near the graduation towers, as well as along ditches with saline water, roads and tracks in the deforested area, situated between the three graduation towers. The complex of saline meadows in the vicinity of graduation towers area, comprising the nature reserve of halophytes was included also to observation.

\section{The study area}

Ciechocinek is one of the most famous health resorts in lowland Poland. At present, seven water intakes are exploited here, and the documented exploitable resources of mineralized waters recognized as therapeutic waters, amount to ca. $500 \mathrm{~m}^{3}$. Three intakes exploit water from the Quaternary aquifer at the depth of 22-24 m. This water has a low mineralization degree and is classified as brackish chloride-sodium and bromide-boric waters. The three deepest boreholes extract the brine from the lower Jurassic and Triassic aquifer layer, at the depth of over 1300-1800 m 
(thermal brine - thermal spring) with the temperature over 25 degrees. The mining area of the health-resort comes to ca. $39 \mathrm{~km}^{2}$.

In the area of the present research, the main objects in the town of Ciechocinek are graduation towers and their more immediate in Spa Park, as well as further surroundings situated in the Torun Valley, in the Vistula River floodplain. Wooden constructions from the 19th century, unique in Europe, built in order to concentrate the brine in the process of salt production, are situated on the low Vistula River floodplain. Three wooden graduation towers built according to the project of Stanisław Staszic have ca. $2 \mathrm{~km}$ in length and ca. $15 \mathrm{~m}$ in height. Oak balks constitute their base, whereas frames are built of pine wood. The interiors of these buildings are filled with brushwood of blackthorn (Prunus padus L.). The condensed brine from the first graduation tower is channelled to the second graduation tower, where it is further condensed and then it is delivered to the third graduation tower, from which the brine is channelled through a pipeline to saltworks. Since 1850, the therapeutic influence on the human organism has been discovered, which soon contributed to the creation and further development of the health-resort.

The reserve of halophytes constituted the second object of the research, with the area of 1.88 ha, created in 1963 and situated within the complex of meadows along the Vistula riverside and arable lands. It was created thanks to efforts of Professor Jadwiga Wilkoń-Michalska from the Nicolaus Copernicus University in Torun. The nature reserve covers a patch of wet meadows between the graduation tower and the flood bank in Ciechocinek, where brine flows down and small salt crystals droop from the graduation towers. A group of specialized plant species grows here, capable of living on the saline soil. These are mainly: Salicornia europaea L., Spergularia marina (L.) Griseb., Glaux maritima L., Aster tripolium L., Triglochin maritimum L., Juncus gerardi Loisel. and Puccinellia distans (Jacq.) Parl. (Nienartowicz \& Warot 2001; Wilkoń-Michalska 1963, 1970; Wilkoń-Michalska et al. 1993, 1997).

\section{Methods}

Floristic studies in the area of the graduation towers in the Spa Park and saline meadows in the Vistula Valley were carried out in 2010 and 2011. Mosses were collected mainly from the soils. The guidebook of Szafran $(1957,1961)$ was used for the identification of taxa. Nomenclature of mosses was accepted after Ochyra et al. (2003). The frequency of taxa occurrence in the study area was described as follows: +++- often, ++- quite often, + rare.

\section{The research results}

In the studied area the presence of 84 species of bryophytes was recorded. The following 9 taxa were the most frequently occurring species (i.e. often according to the applied scale): Bryum argenteum, Ceratodon purpureus, Eurhynchium angustirete, Funaria hygrometrica, Hypnum cupressiforme, Oxyrrhynchium hians, Plagiomnium undulatum, Pohlia nutans, Sciuro-hypnum starkei and Tortula ruralis. 29 species were assessed as quite often, and 45 species were included in the class - rare.

Three strictly protected species are particularly noteworthy: Helodium blandowii, Hypnum pratense and Schistidium flaccidum. The first species was assessed as 'often' in the study area, and the two latter ones were included in the class - rare.

Four other taxa are partially protected and these are: Eurhynchium angustirete, Eurhynchium striatum, Grimmia anodon and Orthotrichum tenellum. The first one often occurs in the study area, the two latter ones are quite often and the last one is rare.

\section{Conclusions}

The flora of bryophytes near the graduation towers in the town of Ciechocinek is rich in species due to very heterogeneous substrates, as well as due to constant inflow of brine near the graduation towers and ditches that discharge the excess brine on the neighbouring meadows. The functioning of the historical system of salt production maintains the gradients of salinity in the landscape and increases the mosaics of habitats. However, the determination of relationships between the distribution of mosses and soil salinity, as well as other environmental gradients needs further observations of vegetation pattern.

\section{References}

Nienartowicz A. \& Warot L., 2001, Ochrona halofitów na Kujawach a zrównoważony rozwój [Protection of halophytes in Kujawy region and sustainable development]. Przegląd Przyrodniczy [Natural Review], Wyd. Lubuski Klub Przyr., 2002: 3-10.

Ochyra R., Żarnowiec J. \& Bednarek-Ochyra H., 2003, Katalog mchów Polski [Census catalogue of Polish Mosses], Polish Academy of Sciences, Institute of Botany, Kraków.

Szafran B., 1957, 1961, Mchy t. 1, 2 [Mosses, vol. 1, 2], PWN, Warszawa.

Wilkoń-Michalska J., 1963, Rezerwat halofilów w Ciechocinku i jego znaczenie [The reserve of halophytes in the 
town of Ciechocinek and its significance], Chronimy Przyrodę Ojczystą, XIII.

Wilkoń-Michalska J., 1963, Halofity Kujaw [Halophytes of Kujawy, in Polish with English summary], Stud. Soc. Toruń., Toruń.

Wilkoń-Michalska J., 1970, Zmiany sukcesyjne w rezerwacie halofitów „Ciechocinek” w latach 1954-1965 [Plant succession in the halophyte reserve "Ciechocinek" between 1954-1965, in Polish with English summary], Ochrona Przyrody 35: 25-51.

Wilkoń-Michalska J., Nienartowicz A. \& Piernik A., 1997. Struktura i funkcjonowanie ekosystemów solniskowych na Kujawach [The structure and functioning of salt marsh ecosystems in the Kujawy Region], [in:]
W. Fałtynowicz, M. Latałowa, J. Szmeja (eds.) Dynamika i ochrona roślinności Pomorza [Dynamics and protection of vegetation in Pomerania] Bogucki Wyd. Nauk., Gdańsk-Poznań: 65-72.

Wilkoń-Michalska J., Nienartowicz A. \& Załuski T., 1993. Zmiany alfa i beta-diversity $\mathrm{w}$ rezerwacie halofitów „Ciechocinek" [Changes in Alfa and Beta diversity in the reserve of halophytes "Ciechocinek"], [in:] A. Kostrzewski (ed.) Zintegrowany monitoring środowiska przyrodniczego [Integrated monitoring of environment], PIOŚ, Instytut Badań Czwartorzędu UAM, Komitet Naukowy przy Prezydium PAN „Człowiek i Środowisko", Warszawa: 259-270. 